\title{
Editorial
}

\section{O futuro da indústria e a indústria do futuro}

$\mathrm{M}$ udanças rápidas dão origem a discussões, medos e apreensões, mas também à esperança, inovação e criatividade. Assim, atualmente, e de forma bem distinta daquelas do começo do século passado - aparece a indústria mostrando seu lado arrebatador, modificador, questionador. Há mais de cem anos, Lorde Kelvin mencionou que não havia mais nada de novo para ser descoberto na Física. Aparentemente ele não tinha todas as informações para fazer esta afirmação, mas uma verdade que ele disse permanece irrefutável: "Se você não pode medir algo, você não pode melhorá-lo"(1). A nascente indústria 4.0 de hoje não pode, como também não conseguiu a pujante indústria do início do século XX, se furtar de tecnologias simples, eficientes, ambientalmente amigáveis e capazes de resolver problemas que não sabíamos ter, pois, como diria Steve Jobs, "muitas vezes, as pessoas não sabem o que querem até mostrarmos a elas"(2).

Plasma sempre será uma das áreas mais fascinantes da pesquisa, tanto básica como aplicada. Com as modificações superficiais induzidas por plasma, coisas surpreendentes podem ser obtidas, como aumento na dureza e/ou resistência a corrosão. Não há dúvidas da importância de modificar substratos bem conhecidos, como o aço, ou novos materiais, normalmente bastante úteis para a indústria aeroespacial, ou mesmo materiais indispensáveis para a medicina moderna. Exemplos de deposição a plasma, já fazem parte do nosso dia a dia, como a camada antirreflexo dos óculos.

Assim, provavelmente a Indústria 4.0 ainda vai ouvir falar muito dessa tecnologia e dessas modificações superficiais, amplamente suportadas pela velha e boa tecnologia de vácuo e que apresentamos nesse número da Revista.

Por fim, a RBAV agradece a todos os participantes do CBRAVIC que enviaram seus artigos para a avaliação em fast track.

\section{The future of industries and the industries of the future}

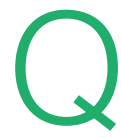

uick changes lead to the raise of not only discussion, fear and concerns but also hope innovation and creativity. Thus, nowadays, in a manner quite distinct of those of the beginning of the past century, industry shows its overwhelming, changeable and questioning side. More than one hundred years ago, Lord Kelvin mentioned that "there is nothing new to be discovered in physics now". Although it seems he has not all the information required to make such statement, the truth that remains is "more and more precise measurement" ${ }^{(1)}$ is required in order to improve something. The upcoming industry 4.0 cannot, the same way the thriving XX century industry couldn't, forbear of technologies that are simple, efficient, environmentally friendly and solver problem for issues we couldn't even foresee the existence or, as Steve Jobs would say, "a lot of times, people don't know what they want until you show it to them"(2).

Plasma always will be one of the most fascinating research areas, either pure or applied science. The plasma induced surface modifications are responsible for surprising things, such as hardness increasing or corrosion prevention. There is no doubt of the importance of modifying well-known substrates, as steel, or new materials, usually essential for aerospace industry, or even indispensable materials for modern medicine. Plasma deposition examples are trivial in our day life, such as anti-glare coating of glasses.

Therefore, probably the industry 4.0 are going to hear about this technology and respective surface modifications, both relying on the good old vacuum technology that RBAV presents on this issue.

Lastly, RBAV thanks all the CBRAVIC attendants that sent their full papers for fast track submission.

Álvaro Jose Damião Antonio Renato Bigansolli Maria Lúcia Pereira da Silva

1. http://scienceworld.wolfram.com/biography/Kelvin.html

2. Steve Jobs Interview: There's sanity returning. Business Week, May 25th (1998) http://www.businessweek.com/archives/1998/ b3579156.arc.htm 